$\mathrm{Y} \Delta \mathrm{K} 321.01$

ББК 66.01

DOI 10.22394/1682-2358-2017-4-119-124

V.N. Gasilin, Honorary Figure of Russian Higher Education, Doctor of Sciences (Philosophy), Professor of the Philosophy Department, Stolypin Volga Region Institute of Administration of the Russian Presidential Academy of National Economy and Public Administration

\section{THE FUTURE \\ OF RUSSIA: PHILOSOPHIC \\ AND \\ METHODOLOGICAL ANALYSIS OF THE A.G. DUGIN'S CONCEPTION}

The essence and conceptions of postmodernism are considered. The conception by A.G. Dugin expounded in a number of works is analyzed. The author redefines the prospects of development of Russia taking into account two alternative myths - the Western and the Patriotic one. The incapacity of the Russian history paradigm by A.G. Dugin is shown.

Key words and word-combinations: the future of Russia, conceptual schemes, paradigm, A.G. Dugin.
В.Н. Гасилин, заслуженньй работник висшей школьг РФ, доктор философских наук, профессор кафедрьг философии Поволжского института упраһления имени П.А. Стольпина филиала Российской академии народного хозяйства и государственной службы при Президенте РФ (email: gasilin2005@yandex.ru)

\section{БУАУЩЕЕ РОССИИ: ФИОСОФСКО- МЕТОАОАОГИЧЕСКИЙ АНААИЗ КОНЦЕПЦИИ А.Г. АУГИНА}

Аннотация. Рассматриваются концепции и сущность постмодернизма на примере работ А.Г. Дугина. Автором переосмысливаются перспективы развития России с учетом двух альтернативных мифов - западного и патриотического. Доказывается несостоятельность парадигмы русской истории А.Г. Дугина.

Ключевые слова и словосочетания: будущее России, концептуальные построения, парадигма, А.Г. Дугин.

$\mathrm{O}$ смыслить перспективы России как государства, как своеобразной цивилизации невозможно без обращения и к ее прошлому, и к настоящему. При этом важное значение имеет философско-методологический подход. Именно с этих позиций проанамизируем концепцию А.Г. Аугина, изможенную им в ряде работ [1-4]. ОАнако наиболее концентрированно и четко она представлена в 3-м разделе книги «Аогос и мифос. Социология глубин» [5], которую испомьзуем при анализе концепџии автора.

Осмысление перспектив развития Рос- 
сии А.Г. Аугин начинает с анализа двух альтернативных мифов - западного и патриотического. Эти направления известны с XIX в. как западничество и славянофильство; термины эти не вполне удачны, невозможно и четкое разделение их сторонников. Но они оказались достаточно живучи, как бы их ни назвали; претерпев определенную трансформацию, они сохранились до настоящего времени, оставив неизменной свое яАро, суть. А.Г. Аугин полагает, что оба мифа «предельно несостоятельны».

Что касается первого, суть которого состоит в ориентаџии на ЗапаА, сбцижение с Западом путем модернизации, то главная причина его несостоятельности состоит в том, что «современный ЗапаА, Авигаясь по своей траектории развития, перешел из состояния модерна к состоянию постмодерна» [5, с. 247]. Это состояние не явцяется продолжением модернизации и ни к чему привести не может. «Негативные» характеристики постмодернизма, которые он несет для общества, А.Г. Аугин формулирует как «освобождение индивидуума от всего остального, кроме индивидуума». Эго освобождается от себя, чтобы открыть индивидуальное подсознание. Это общефилософские утверждения.

В социально-философских аспектах они состоят в том, что демократия в «постмодернистском обществе» - это не власть большинства, а зашита интересов меньшинства. Нет никакой коммективной идентификации, а только индивидуальная. Это звучит по крайней мере странно, поскольку индивидуальная идентификация внутренне связана с коммективной. Но продолжим Аугинскую характеристику постмодернистской характеристики: «...на смедующем этапе уже сами граждане начали фрагментироваться, распадаться на части...» [5, с. 249]. На наш взгляА, эти утверждения о постмодернизме не явцяются корректными, что и попытаемся показать.

Обратимся к источникам, включающим обобщающую характеристику постмодернизма. «Постмодернизм - тенденции, проявившиеся в культурной практике и самосознания Запада в течение двух последних десятилетий» [6, с. 197]. Постмодернизм возник впервые как течение в искусстве (архитектуре, Аитературе). Его превращение в философское явление (как термин, категория) произошло с появлением работы Ж.-Ф. Аиотара «Состояние постмодерна». Ао этого термин «постмодерн» функционировал как термин искусствоведческий, термин митературоведческий, но никак не философский. «Состояние постмодерна», которое обсуждает в своей работе Ж.-Ф. Аиотар, относится к науке, а точнее к отношению к «метарассказу». «Философ может по меньшей мере успокоить себя, сказав... что его помещают в опредеменные рамки» [6 с. 13].

Вот это и является, на наш взгляд важным, поскольку у Ж.-Ф. Аиотара идет речь о научных изменениях, а не об изменениях в культуре вообще. Обратимся к общеупотребительным смыслам термина «постмодернизм». Определение из словаря: «Постмодернизм - понятие, используемое в современной философской рефмексии дмя обозначения характерного Аля культуры сегодняшнего Аня типа философствования...» [7, с. 779]. Еще оАно опреАемение, которое ставит фактически точку на понимании постмодернизма, дано 
одним из главных специалистов в этой области: И.П. Ильин определят это понятие как непредсказуемое новое, «грядущие контуры которого неясны и не обещают ничего опредеменного и надежного...» [8, с. 234] .

Таким образом, постмодернизм как одно из направлений безусловно существует, но оно не является ведущим, определяющим даже облик современной философии, и тем более соџиально-философские и социально-политические конџепџии. На простой вопрос: кто из ведущих современных политиков придерживается постмодернистской ориентации - вряд Аи кто способен ответить. Современные политические мидеры далеки от этой философской проблемы, а это свидетельствует о том, что постмодернизм существует и распространяется в среде элитьи, но никак не явмяется сочиально-политическим Авижением современной фимософии.

Это не открытая антимарксистская позиция, это реалия. Вот что привеА один из признанных исследователей деконструктивизма и постмодернизма И.П. Ильин, сославшись на одного из мидеров постмодернизма Ж. Аеррида, который заявлям: «Хотя я не явмяюсь и никогда не был ортодоксальным марксистом, я весьма огорчен тем антимарксизмом, который господствует сейчас во Франщии (речь шла о 80-х годах XX в. - В.Г.), и в качестве реакщии на это, а также по политическим соображениям и кичным предпочтениям я склонен считать себя большим марксистом, чем я был в те времена, когда марксизм был своего рода крепостью» [9, с. 104] .

Отметим, что постмодернизм возник прежде всего как литературное Авижение и на этом «заџикликся». Не случайно его характеризуют так: «литературность как придание миру смысла», «обшество спектакля», «шоу отменяет историю и т.п. [9, с. 170-183] .

Итак, все ссылки на постмодернизм в ориентации российской политики по крайней мере мало убедительны. Кмюч рассуждений А.Г. Аугина закмючается в том, что ориентация на ЗапаА - прогрессивная тенденция, но она нам не поможет. И с этим можно вполне согласиться. Аа, ЗапаА достиг несомненных успехов в различных областях, но это отнюдь не означает, что дальнейший путь развития России следует копировать с Запада. В этом А.Г. Аугин прав - этот путь мифический.

Более сложным представмяется второй путь, обозначаемый автором как «патриотический миф». Он образно выражается в следуюшем: «Мы русские молодџы; у нас, у русских, есть собственная идентичность, своя наџиональная идея, и нам надо мишь отказаться от мирового правительства, мировой глобализации, повернуться спиной к миру, и все сложится» [5, с. 257]. А что, собственно, у нас есть, чтобы строить будушее России? По мнению А.Г. Аугина, у нас нет «никакого самостоятельного соџиального могоса», «нет внятной конџепџии», «нет продуманной конструкции идентичности», «нет самостоятельной философии» [10], нет «соџиально-философских преАпосынок» и т.п. Это представмяется весьма сомнительным по всем перечисменным пунктам.

«Конструктивное предложение» А.Г. Аугина: осмыслить актуальный покитический момент в современной русской истории по ту сторону Авух 
неадекватных мифов - как миберально-западнического, так и патриотического. «Нам надо иметь перед глазами парадигму национальной истории» [5, с. 259], а у нас ее нет, по мысли А.Г. Аугина.

А какие были? Марксистская парадигма рухнула. Но рухнула ми? Формационная идея К. Маркса имеет под собой весьма основательную базу. Разве историки, соџиологи, политологи, философы не продолжают делить историю на определенные периоды (без этого просто невозможно продуктивное научное исследование) ? Эта схема проста: первобытное общество, рабовладельческий строй, феодацизм, капитализм, соџиализм, а потом коммунизм. Традиционная марксистская парадигма, как пишет А.Г. Аугин, рухнула, а почему же до сих пор исследователи используют термины этой «рухнувшей» парадигмы? Потому что от идеи разделения истории человеческого общества на опредеменные периоды никуда не уйти.

Если же, преАположим, все-таки рухнула, то что пришло ей на смену в нашем Отечестве? Вот ответ А.Г. Аугина: «Аичайшие формы самого разнузданного, омерзительного капитацизма со всеми его «прелестями»... гигантским андеркмассом в 5 мимлионов (кюдей, живущих в России под чертой бедности), катастрофическим расслоением общества, беспризорностью и т.А.» [5, с. 260] .

Аалее - новая формаџия мибералов, уже 1990-х годов. ФонА Сороса, преАставивший многотиражные учебники по русской истории в совершенно "Аиком» изложении, Россия - это дикарская страна. «По Соросу, так в России бымо всегда, пока не пришии академик Сахаров и Елена Боннэр... которые открыли глаза, пообещав: сейчас мы научим вас правам человека, мы научим вас демократии. Ну и их «пророк» Валерия Новодворская. Вместе они создали новый, «правильный мир». Русская история начинается с Сахарова, Боннэр, Новодворской... а все остальное кровавая, черная прелюдия к их появлению...» [5, с. 261], что представляется очень странным. Фонд Сороса сыграл в целом негативную роль в постсоветской истории России, а многие были ослеплены его «подАержккой» и «подачками». Но суть Аела, как представляется, все же в Аругом. Нападки А.Г. Аугина на марксистскую парадигму оставцяют ей право на существование, но, как он полагает, ее сторонникам преАстоит проделать «колоссальную методологическую работу по пересмотру основных моментов» [5, с. 261]. Насчет «колоссальности» мы все же сомневаемся, Аажке не будучи сторонниками этой позиции. Но в своем утвержкдении он в целом прав. Он - исследователь, стремящийся мыслить глобально, но не прав, как философ, передергивающий факты русской истории.

А.Г. Аугин полагает, что сегодня отсутствует парадигма русской истории. «Русское прошлое есть, а внятной русской истории нет». Он настаивает на том, что у истории нет никакой могики и полагает, что вся история у нас (Аа, видимо, и не только у нас) сводилась к перечислению исторических событий. На наш взгляА, это ошибочное заключение. История есть, Аругое Аело, как эта история (прошиые события) трактовалась и продолжает трактоваться. А это уже целиком на совести историков как специалистов по толкованию и интерпретации. 
Центральной проблемой, по мысли А.Г. Аугина, явмяется поиск парадигмы для объяснения русской истории. В качестве основания такой парадигмы он предлагает рассматривать "Ауализм государства и народа» [5, с. 264] как наиболее яркое проявление правящего класса и народа. Это заключение ведет автора к Аругому противостоянию: «Русь» и «славяне». Аалее же он воспроизводит русскую историю в соответствии с той «схемой», которую отвергал ранее («исторической схемой»).

Фицософско-методологический аспект подхода А.Г. Аугина включает употребление им термина «парадигма», который в методологический обиход впервые ввеА Т. Кун применительно к описанию и осмыслению развития науки. С тех пор этот термин, как и термин «эпистема» (М. Фуко), получиц широкое распространение даже в тех областях исследования, которые далеки от науки.

ОАнако Т. Кун не преАложиц, как это ни странно, четкого строгого логического опредемения понятия «парадигма». Его определение состоит в следующем: парадигма - это понятие, причисленное к «...признанным всеми научным достижениям, которые в течение опредеменного времени дают модемь постановки проблем и их решений научному сообществу» [11, с. 11]. Аюбопытно, что в поздний период творчества Т. Кун заменил это понятие термином «матрица». Можно предложить переформулировку этого понятия: «Парадигма» - это совокупность правил и методов постановки и решения научных проблем, которые приняты определенным научным сообществом в определенное историческое время.

В качестве парадигмы истории российского общества А.Г. Аугиным предлагается соотношение правящего кмасса и народа (ики в исходном смысле - «Русь» и «славяне», славяне в смысле «народ»). Эта парадигма, по мысли автора, в состоянии объяснить особенности и спещифику русской истории. Возражение против такой позиџии автора состоит в следующем: а разве такого противостояния не было ранее в Аругих госуАарствах, у разных народов? Было всегда, в разных формах. Тогда неясно, в чем специфика предкагаемой А.Г. Аугиным «парадигмы».

Вопрос, которым заканчивает А.Г. Аугин: «Куда идти, когда идти больше некуда?» [5, с. 278]. «У нас нет эпистемы, у нас нет пространства, гАе миф народа мог бы контактировать с могосом государства. Значит, мы должны выковать эту эпистему и создать такое пространство» [5, с. 279]. На смену термина «парадигма» вдруг приходит термин «эпистема». Это не небрежность, это теоретическая непоследовательность, связанная с недопониманием Аанных терминов. Слово «парадигма» употребцяется в данном случае некорректно, поскольку относится к цогико-методологическому полю, задача которого состоит в объяснении и понимании решения проблемы. Предлагаемая «парадигма» ничего ни объяснить, ни тем более понять внятно не позволяет, а уж тем более ответить на вопрос: «Куда идти?».

Развитие России в последнее десятиметие свидетельствует о том, что нельзя бросаться в крайности, тем более те, которые обрисовац А.Г. Аугин; крайности, противоположности следует объединять, синтезировать, по законам диа- 
мектики. Это глобальная задача, которая требует постоянных, ежедневных усилий при учете главного: Россия Аолжна эффективно интегрироваться в мировое сообщество, не потеряв своей идентичности.

\section{Библиографический список}

1. Дугин А.Г. Обществоведение для граждан Новой России. М., 2007.

2. Дугин А.Г. Геополитика постмодерна. СПб., 2007.

3. Дугин А.Г. Философия политики. М., 2004.

4. Дугин А.Г. Философия традиционализма. М., 2002.

5. Дугин А.Г. Логос и мифос. Социология глубин. М., 2010.

6. Лиотар Ж.-Ф. Состояние постмодерна / пер. с франц. Н.А. Шматко. М.; СПб., 1998.

7. Новейший философский словарь. 3-е изд., испр. Мн., 2003.

8. Ильин И.П. Постстркуктурализм. Деконструктивизм. Постмодернизм. М., 1996.

9. Ильин И.П. Постмодернизм от истоков до конца столетия: эволюция научного мифа. M., 1998.

10. Гасилин В.Н., Дмитриева В.А. Есть ли русская философия: по поводу концепции А.Г. Дугина // Человек. История. Культура: исторический и философский альманах. Саратов, 2011. № 10. С. 5-21.

11. Кун T. Структура научных революций / пер. с англ. М., 1975. 